Ministry of Agriculture and Fisheries (1953). Sea Fish. Res. Notes, 32, 7.

Sverdrup, H. U. (1952). Fish. Bull. F.A.O. 5, no. 6.

United Nations Organization (1957). U.N. mon. Bull. Statist. Ir, no. 8.

United Nations Organization: Department of Social Affairs (1956). U.N. Demographic Yearbook I956. New York: United Nations Organization.

United Nations Organization: Statistical Commission (1957). U.N. Statist. Pap. Ser. A, 9, no. 3.

Walford, L. A. (1951). In Proceedings U.N. Department of Economic Affairs, United Nations Scientific Conference on the Conservation and Utilization of Resources. 7. Wildlife and Fish Resources, p. 60.

Woodward, F. H. (1952). World Crops, 4, 4०3.

\title{
The food supplies of the fish
}

\section{By J. H. Fraser, Scottish Home Department Marine Laboratory, Aberdeen}

The food of fish and where their food supplies come from is very much to the point as essential background in a symposium on world fish supplies.

The more food there is available for fish the bigger and better they grow, within limits, age for age. For example, a 5 -year-old haddock living on the moderately good food supplied by the central North Sea grows to a length of $3 \mathbf{I}^{\cdot} \cdot 6 \mathrm{~cm}$, but a 5-year-old haddock from the rich feeding in Icelandic waters grows to about $55 \mathrm{~cm}$ ('Thompson, 1929) which is about five times the weight. If there is too much competition for food, fish do not grow so well and are of poor quality. This may happen in underexploited areas and, as more fish are taken from such grounds, quality improves. What happens when there is overexploitation is the subject of the next paper (Gulland, 1958), but it is obvious that no amount of conservation can increase the total weight of fish available beyond the limits imposed by its own food supplythough efforts can be directed to help ensure that the available food is used to the best advantage.

\section{Productivity in the sea}

With that in mind we can then consider the nature of this food and trace the food up from the fundamental source in the green photosynthetic plants. The main difference between the agricultural and aquatic environments is that on the land the water is in dark interstitial cavities between fairly stable soil particles and the light is in the air above; in the sea there is no such stability and no such division. Light for effective photosynthesis will not penetrate far enough to reach the bottom except in very shallow areas around the sea coast-a much too small a fraction of the total surface of the sea to concern us in this question, and one that we can ignore. There can be no holdfast in the open sea and the plants must float in the light zone, and floating be carried by the water movements from place to place both horizontally in the currents and vertically in areas of turbulence. As many of these small autotrophic plants cannot photosynthesize in an excess of light it may be just as unproductive for them to be brought too near the surface as to be taken down too deep. Their growth is, of course, dependent upon the dissolved nutrient salts and metabolites as well as the light. The greatest bugbear for the research worker in these 
fields is his inability to sample the same water, or the same population, even twice; there is always some movement, some dispersal or intermixing.

To enable them to float, these autotrophic plants are minute-the flagellates as small as $\mathrm{I}-2 \mu$ to the larger diatoms rarely more than $25^{\circ} \mu$ in diameter. Some are liberally provided with spines which increase their surface area and thus their floatation, others produce oil globules which reduce their specific gravity. Living in the light zone they gradually utilize the nutrients there which can only be replaced by excretion or by regeneration from dead organisms in the same zone, or by upwelling of deep water rich in nutrients from below the light zone-nutrient-rich because it is a zone of regeneration without utilization. In the tropics there is a stable layer of surface water warmed by the sun, so that there is little replenishment of nutrient from below and plankton production is poor except in areas of upwelling, such as off the west coast of South Africa and South America where constant offshore winds drive off the surface water and the rich water from below upwells to take its place. Here, according to Steemann Nielsen \& Jensen (I957), production is about twenty times greater than in the open ocean at the same latitude, or fifty times that in the Sargasso Sea. The standing crop in the tropics is also small because of the quick growth and short life cycles of the organisms there. In the Arctic, there is no such temperature stability of the surface layers and there is much natural turbulence so that production there is rich in spite of the colder water and poorer light, and the standing crop is further increased because of the slower growth and longer life span of the organisms in the colder water. Upwelling on the edges of the continental shelves can also be very important and be responsible for the richness of the fisheries on the shelf. In all, Steemann Nielsen \& Jensen (1957) estimated that about ${ }_{1} \cdot 2-1 \cdot 5 \times 10^{10}$ tons of carbon are produced annually in the oceans which, from the conversion data of Fleming ( 1940 ), is equivalent to 30,000 million tons dry weight or 500,000 million tons wet weight of organic matter, figures that are not far different from those for total production on the land. Other workers, e.g. Ryther (1954), think Steemann Nielsen's figures are underestimates.

\section{Plankton and the food chain}

Feeding on these plants are a vast array of herbivorous animals, in their turn to be fed on by the carnivores, the whole community being planktonic. The word plankton is a composite term for all those organisms, plant and animal, that are drifted about by the movements of the water rather than by any swimming powers of their own. Some of the zooplankton organisms are holoplanktonic and will live in the plankton all their lives; others are the planktonic larvae of creatures like crabs, worms, shellfish, starfish and the young fish themselves which will eventually metamorphose and go to the bottom to live. What isn't eaten and assimilated, one way or another, is disintegrated by bacteria, thus regenerating nutrients for both autotrophic and heterotrophic plants, and the bacteria themselves form the food of protozoa and other animals. Small particles of organic matter (leptopel), protozoa and bacteria all form the food of the filter feeders, some of which are planktonic but 
many live on the bottom, such as worms and the cockles, mussels and other bivalve molluses, which form the food of the demersal fish.

Because different water masses of different origins and with differing nutrient and metabolite contents are constantly on the move and mixing, the primary production will vary according to the hydrographical conditions and also to the biological history of the water but, generally speaking, the greater the mixing the richer the plankton. Fish such as herring, sprat and pilchard as well as the big whalebone whales feed directly on the plankton. A blue whale is born about $26 \mathrm{ft}$. long after a year's gestation and weighs 12 tons (Jenkins, I932). The calf then increases during the lactation period to about $50 \mathrm{ft}$. in about 7 months while the mother feeds on plankton. The weight of herring landed annually from the North Sea is about $1 \frac{1}{2}$ million tons $(\mathrm{I}, 4 \mathrm{I} \mathrm{I}, 220,000 \mathrm{~kg}$ in 1955$)$ and from the north-eastern Atlantic is about $2 \frac{1}{2}$ million tons $(2,621,468,000 \mathrm{~kg}$ in 1955$)$ (International Council for the Exploration of the Sea, 1957, Table 4), mainly produced by direct feeding on zooplankton.

\section{The food of demersal fish}

Most other familiar fish are demersal, mainly feeding on the animals on or near the bottom, but feeding habits of different fish vary both according to what is available season to season, and to some extent on the locality but particularly according to the likes and dislikes of the variety of fish. This last is particularly important in the competition for food and some species can thrive in places where there is only a poor food supply for others. Some fish are indiscriminate feeders but others are meticulously finicky. Cod, for example, feed mostly on crustacea and on other fish, both near the bottom and pelagic species, but will take most other things also (Brown \& Cheng, 1946). Haddock is a very catholic feeder but mostly on organisms on the bottom (Ritchie, 1938); whiting feed more on the active swimming crustacea and other fish (Jones, 1954). Plaice feed mostly on annelid worms but take also some molluscs, echinoderms, crustacea and fish (Ritchie, 1938). Lemon sole feed also on worms but not the same dominant species; they take hermit crabs too, like the cod, but only the young cod are competing for the same size-range (Rae, 1956). The big halibut, though they are flatfish, tend to feed largely off the bottom on fish (McIntyre, 1952). On the whole, it can be said that because of these preferences for different foods and because of habitat preferences, some fish liking hard ground and others a soft bottom-there is probably not a great deal of interspecific competition for food amongst the familiar food fishes.

Food has other points of interest to nutrition experts. It can affect flavour and it can affect items such as the vitamin A content of the liver. Halibut, for example, is well known to have a rich content of vitamin A in the liver. Its principal food is Sebastes (the red fish found abundantly in the deep North Atlantic and prized very highly on the American table but, the more is the pity, not here), and Sebastes-liver oil has a higher vitamin A content than cod-liver oil. It is unlikely that fish can synthesize vitamin A themselves so that its origin is in turn, through their various foods, from the plankton. 
The food of even the bottom-living animals is dependent upon plankton in one or more of several ways. Many of their larvae are planktonic, feeding on the plankton directly at this stage, being drifted about by the currents. There is evidence for their dependence for their growth and ability to metamorphose on the very dilute organic contents in the water (cf. Wilson, 1951; Collier, Ray \& Wilson, 1956), and these have most likely been produced originally by the plankton. 'Thus, their place of settlement and their abundance at that time-their brood survival-are both dependent upon planktonic conditions. Having settled down to grow on the bottom they will probably be eventually eaten by something else. Until then, they are dependent for their survival on their food which is obtained from the plankton, either directly or by filter feeding on the products of disintegrated plankton or by being carnivorous on other animals which are so dependent.

We thus have a picture of the food chain in the sea and the dependence of fish, whether they are herring feeding directly on zooplankton or halibut feeding on carnivores in deep water, on the fundamental production of the autotrophic phytoplankton. And it in turn is dependent on photosynthesis and the distribution of dissolved nutrient salts. Thus we get a link between the yield of the fisheries and the fertility of the sea, not necessarily the fertility of the water actually on the fishing grounds but the fertility in the areas of mixing from which the water and its contents will gradually drift, changing all the while, until it arrives on the fishing grounds.

\section{The young stages of fish}

But there is more to the story yet. The eggs of most commercial fish (except herring) float in the plankton, and after hatching the young fish for the first few weeks of their lives are themselves part of the plankton and live and feed there. This means two important things toward their survival. First that there must be sufficient food of the right kind available after they hatch and when their tiny mouths are first formed. It must be abundant enough for them to find it without too much effort. Second, they must be drifted by the water movement to suitable areas so that when they become demersal fish they are within reach of the right kind of bottom, with the right kind of food and within acceptable limits of depth. These nursery areas are thus not the same places as the spawning areas unless there is an eddy system in operation and many, many young fish will be lost to the brood by early starvation, by being in the wrong place at metamorphosis or by being eaten by predatory species, so much so that it is now recognized that numbers of annual recruits to the fisheries may not be so much dependent upon the number of eggs laid as on what happens to them afterwards.

\section{The yield of fish}

The food of fish, then, is a complicated story of so many variable conditions from meteorology, hydrography, bacteriology, biochemistry and biology; just as complicated as on the land but with the added factors of variable movement and variable mixing of the whole environment. At each stage of the food chain about $90 \%$ is lost so that $100 \mathrm{~g}$ of autotrophic diatoms yield $10 \mathrm{~g}$ of herbivorous animal, 
$\mathrm{I} g$ of carnivorous animal and $0 . \mathrm{I} g$ of fish if it feeds directly at this stage, or $0.0 \mathrm{I} g$ at one stage further removed. The 500,000 million tons of autotrophic plants I mentioned yielded, according to F.A.O. statistics, only 27.7 million tons of fish on the world's markets in 1955 . This does not seem much, but the production figure covers the whole ocean where little commercial fishing is possible. In the North Sea, which is a eutrophic area, between 0.2 and $0.3 \%$ of the carbon fixed is taken out by fishermen (Steemann Nielsen \& Jensen, 1957). This high figure is partly due to the large proportion of herring in the catches, and herring are feeding mostly at only one stage removed from the primary production. It is also probably in part due to the current systems bringing into the North Sea middle stages of the food chain which have had their primary origin outside the North Sea boundary. This figure for the North Sea could be increased, within limits, by optimum exploitation.

\section{Fertilization and direct use of plankton}

Two related topics that are, strictly speaking, outside the title of this paper, should receive brief mention. Can we use the plankton more directly for human consumption or as animal feed and so get the benefit of some ten to a hundred times the available tonnage? And can we increase the phytoplankton and so the fish by artificial fertilization?

Great success has been achieved by the artificial fertilization of freshwater and brackish fish ponds, particularly in the warmer countries where carp and other mostly herbivorous fish are grown. Fertilization can be effective in a much more limited way in small semi-enclosed sea lochs or inlets, as it has been shown that the nutrients are quickly absorbed and there may be less tendency for them to be washed out to sea than expected (Nutman, 1950). In the limited areas so far tried the environmental conditions are not conducive to the growth of those fish the housewife wants so that there is not yet much hope of a commercial success, even if there is much of scientific value. In the open bays we are up against something very different in that the fish are not static. Such bays may be excellent nursery grounds, but as the fish move out to deep water before they reach marketable size there would be no easy means of assessing the value of the experiment. Fertilization of the open sea by adding expensive chemicals is beyond man's resources. There is in the sea any amount of nutrient in the deeper waters; far better to try to extract it for use on the land than to pour it back.

Can we ourselves utilize plankton to better advantage? There is plenty of it to be had for the taking-but can we take it? If we try a net to catch it we are immediately in difficulties. Plankton organisms are of such a size range that there is no ideal mesh of net. Either one can filter vast quantities of water with a coarse mesh and catch only the larger animals, or use a smaller mesh that cannot pass the flow quickly enough to separate the smaller organisms from more than proportionately smaller quantities of water. Similarly, if one uses a centrifuge one can separate a few larger organisms by a short spin or more smaller organisms by a longer spin. In either way there is no known way to catch sufficient plankton for economic returns for the 
effort spent: like getting gold from sea water, there is plenty there but it costs more in cash to get it than the value of the return. Jackson (1954) calculated the cost of various methods and returns and concluded that plankton would cost about twenty times the figure charged for the highest priced fish. This might be worth it for some special compound of great pharmacological value, but not for animal feeding.

No, with engineering difficulties and costs as they stand now-and this does not necessarily also mean in the future-it is far better to let the various marine organisms work for us, free of charge, $24 \mathrm{~h}$ a day, no overheads and no strikes, and then catch the resulting fish rationally even if they do represent only a fraction of the actual production of the sea.

\section{REFERENCES}

Brown, W. W. \& Cheng, C. (1946). Hull Bull. mar. Ecol. 3, no. 18, p. 35.

Collier, A., Ray, S. \& Wilson, W. B. (1956). Science, 124, 220.

Fleming, R. H. (1940). Proc. Sixth Pacif. Sci. Congr., California, 1939, 3, 535.

Gulland, J. A. (1958). Proc. Nutr. Soc. 17, 132.

International Council for the Exploration of the Sea (1957). Bull. statist. Pêch. marit., Copenh., 40, 6.

Jackson, P. (1954). F. Cons. int. Explor. Mer, 20, no. 2, p. 167.

Jenkins, J. T. (1932). Whales and Modern Whaling. London: Witherby.

Jones, R. (1954). Mar. Res., Scot., no. 2, p. I.

McIntyre, A. (1952). Mar. Res., Scot., no. 3, p. I.

Nutman, S. R. (1950). Proc. roy. Soc. Edinb. B, 64, no. I, p. 5.

Rae, B. B. (1956). Mar. Res., Scot, no. 3, p. I.

Ritchie, A. (1938). Rapp. Cons. Explor. Mer, 107, 49.

Ryther, J. H. (1954). Deep-Sea Res. 2, I 34.

Steemann Nielsen, E. \& Jensen, E. A. (r957). 'Galathea' Rep. 1, 49.

Thompson, H. (1929). Rapp. Cons. Explor. Mer, 57, 3.

Wilson, D. P. (1951). भ. mar. biol. Ass. U.K. 30, г.

\section{The conservation of fish stocks}

\section{By J. A. Gulland, Fisheries Laboratory, Lowestoft}

Covering as they do seven-tenths of the earth's surface, the seas and oceans of the world have been, and seem likely always to be, an important source of supply of man's food. Though now, and for the foreseeable future, fishing may be likened to hunting, rather than to agriculture and, at least in the open sea, nothing can be done directly to improve the stock of fish, the future of a fishery can be greatly affected by the quantity and quality of the catch removed from the stock. Conservation of fish stocks is therefore concerned with suitable regulation of fishing (how much and what sort of fish to catch), and the main problems are firstly establishing the facts as to how fishing controls the level of the stocks and hence future catches, and secondly deciding in the light of these facts how the fishery should be regulated to the best interests of all concerned in it, producer and consumer, present and future.

The influence that intensive fishing could have on fish stocks first became apparent at the end of last century when the rapid expansion of steam trawling in the North Sea was followed by an almost equally rapid decline in the abundance of the most 